\title{
Bismuth(III) Iodide Complexes with 1-Ethyl-4- Dimethylaminopyridinium: Structure, Thermal Stability, and Optical Properties
}

\author{
A. N. Usol'tsev ${ }^{a, *}$, I. A. Shentseva ${ }^{a, b}$, V. R. Shayapov ${ }^{a}$, P. E. Plyusnin ${ }^{a}$, \\ I. V. Korol'kov ${ }^{a}$, M. N. Sokolov ${ }^{a}, c$, and S. A. Adonin ${ }^{a}$ \\ ${ }^{a}$ Nikolaev Institute of Inorganic Chemistry, Siberian Branch, Russian Academy of Sciences, Novosibirsk, 630090 Russia \\ ${ }^{b}$ Novosibirsk State University, Novosibirsk, 630090 Russia \\ ${ }^{c}$ Kazan Federal University, Alexander Butlerov Institute of Chemistry, Kazan 420008 Russia \\ *e-mail: usoltsev@niic.nsc.ru \\ Received March 10, 2021; revised March 30, 2021; accepted April 5, 2021
}

\begin{abstract}
Polynuclear bismuth(III) iodide complexes with 1-ethyl-4-dimethylaminopyridinium

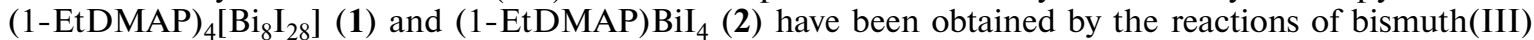
iodide with an organic iodide salt cations in organic solvents and characterized by X-ray diffraction. The optical properties and thermal stability of the obtained compounds have been studied.
\end{abstract}

Keywords: bismuth, halide complexes, polynuclear complexes, coordination polymers, optical properties

DOI: $10.1134 /$ S0036023621100193

\section{INTRODUCTION}

Interest in the chemistry of halide complexes of $p$-elements is largely due to the variety of their structural types [1]. For example, halogen bismuthate anions can have molecular structure with a nuclearity from 1 to 8 [2-11]. A large number of complexes with polymer anions are also known, usually one-dimensional [12-19]; examples of two-dimensional anions are extremely rare [20]. On the other hand, halogenated metals [21-23] can possess a number of physicochemical properties that are of interest from the point of view of materials science. These include, in particular, thermochromism [24-30] and photochromism [31, 32]. The most actively developing areas include the study of solar cells and photodetectors based on iodometallates, especially iodoplumbates(II) [33-36]. The latter circumstance predetermines the increased interest in iodide complexes. However, as it was repeatedly noted earlier [1], there are still no known approaches that allow one to obtain compounds of this class with a pre-planned structure. Screening using a wide range of organic cations as salt precursors remains the most rational way to search for halogenated metalates that are promising from the point of view of materials science.

In this work, we obtained and structurally characterized two new bismuth iodide complexes with 1-ethyl4-dimethylaminopyridinium cation (-EtDMAP), namely (1-EtDMAP) $)_{4}\left[\mathrm{Bi}_{8} \mathrm{I}_{28}\right]$ (1) and (1-EtDMAP)BiI
(2). Their structure and preparation conditions, as well as optical properties and thermal stability are discussed.

\section{EXPERIMENTAL}

Compounds $\mathbf{1}$ and $\mathbf{2}$ were synthesized in air. Reagents of the chemically pure grade (Russian State Standard) were obtained from commercial sources and used without further purification. 1-EtDMAP iodide salt was obtained by the reaction of 4-dimethylaminopyridine and ethyl iodide $(1: 1)$ in $\mathrm{CH}_{3} \mathrm{CN}$ (reflux, $18 \mathrm{~h},>90 \%$ yield); the purity was verified by ${ }^{1} \mathrm{H}$ NMR spectroscopy and elemental analysis.

Synthesis of (1-EtDMAP) ${ }_{4}\left[\mathbf{B i}_{8} \mathbf{I}_{28}\right]$ (1). Weighed portions $\mathrm{BiI}_{3}(100 \mathrm{mg}, 0.17 \mathrm{mmol})$ and 1-EtDMAP-I ( $24 \mathrm{mg}, 0.8 \mathrm{mmol}$ ) were dissolved in $\mathrm{CH}_{3} \mathrm{CN}(15 \mathrm{~mL})$ when heating to $80^{\circ} \mathrm{C}$ for $1 \mathrm{~h}$. After dissolution, the mixture was slowly cooled to room temperature and the solvent was evaporated. After partial evaporation of the solvent at room temperature, dark red crystals were obtained. Yield, $49 \%$.

For $\mathrm{C}_{36} \mathrm{H}_{60} \mathrm{~N}_{8} \mathrm{Bi}_{8} \mathrm{I}_{28}$ anal. calcd. (\%): C, 7.4; $\mathrm{H}, 1.0$; N, 1.9.

Found (\%): C, 7.7; H, 1.0; N, 2.0.

Synthesis of (1-EtDMAP)BiI ${ }_{4}$ (2). Weighed portions of $\mathrm{BiI}_{3}(59 \mathrm{mg}, 0.1 \mathrm{mmol})$ and 1-EtDMAP-I (28 mg, $0.1 \mathrm{mmol}$ ) were dissolved in $3 \mathrm{~mL}$ of a mixture of $\mathrm{CH}_{3} \mathrm{CN} /$ acetone $(1: 1)$ solvents when heating to 
Table 1. Crystallographic data and experimental and refinement details for compounds $\mathbf{1}$ and 2

\begin{tabular}{|c|c|c|}
\hline Parameter & 1 & 2 \\
\hline Formula & $\mathrm{C}_{36} \mathrm{H}_{60} \mathrm{Bi}_{8} \mathrm{I}_{28} \mathrm{~N}_{8}$ & $\mathrm{C}_{18} \mathrm{Bi}_{2} \mathrm{I}_{8} \mathrm{~N}_{4}$ \\
\hline$F W, \mathrm{~g} / \mathrm{mol}$ & 5829.96 & 1705.38 \\
\hline Crystal system, space group & Triclinic, $P$ & Monoclinic, $P 2_{1} / n$ \\
\hline$a, b, c, \AA$ & $10.5157(7), 13.3901(7), 19.6508(10)$ & $13.8281(5), 18.5468(4), 15.5983(5)$ \\
\hline$\alpha, \beta, \gamma, \operatorname{deg}$ & $\begin{array}{c}89.739(4), 85.684(5) \\
67.030(5)\end{array}$ & $113.841(4)$ \\
\hline$V, \AA^{3}$ & $2539.4(3)$ & $3659.1(2)$ \\
\hline$Z$ & 1 & 4 \\
\hline$\rho_{\text {calcd }}, \mathrm{g} / \mathrm{cm}^{3}$ & 3.812 & 3.096 \\
\hline$\mu, \mathrm{mm}^{-1}$ & 22.35 & 16.37 \\
\hline$F(000)$ & 2480 & 2904 \\
\hline$\theta$ range, deg & $\theta_{\max }=25.7, \theta_{\min }=3.3$ & $\theta_{\max }=29.0, \theta_{\min }=3.3$ \\
\hline$h k l$ index ranges & $\begin{aligned} h & =-12 \rightarrow 12 \\
k & =-16 \rightarrow 16 \\
l & =-22 \rightarrow 23\end{aligned}$ & $\begin{aligned} h & =-18 \rightarrow 14 \\
k & =-19 \rightarrow 25 \\
l & =-16 \rightarrow 19\end{aligned}$ \\
\hline $\begin{array}{l}\text { Number of reflections: } \\
\text { collected } \\
\text { independent }(N)\end{array}$ & $\begin{array}{c}20264 \\
9640\end{array}$ & $\begin{array}{l}1856 \\
8070\end{array}$ \\
\hline$R_{\mathrm{int}}$ & 0.030 & 0.027 \\
\hline$N$ with $I>2 \sigma(I)$ & 7789 & 7134 \\
\hline$R\left[F^{2}>2 \sigma\left(F^{2}\right)\right], w R\left(F^{2}\right), S$ & $0.052,0.164,1.12$ & $0.030,0.102,0.73$ \\
\hline$\Delta \rho_{\max } / \Delta \rho_{\min }, \mathrm{e} / \AA^{3}$ & $3.23 /-2.96$ & $1.08 /-2.39$ \\
\hline
\end{tabular}

$80^{\circ} \mathrm{C}$ for $1 \mathrm{~h}$. After dissolution, the mixture was slowly cooled to room temperature and kept for a day. Dark red crystals were obtained. Yield, 52\%.

For $\mathrm{C}_{9} \mathrm{H}_{15} \mathrm{~N}_{2} \mathrm{BiI}_{4}$ anal. calcd. (\%): $\mathrm{C}, 12.5 ; \mathrm{H}, 1.7$; $\mathrm{N}, 3.2$.

Found (\%): C, 12.7; H, 1.5; N, 3.0.

$\mathrm{X}$-ray diffraction. Diffraction data for single crystals of compounds $\mathbf{1}$ and $\mathbf{2}$ were obtained at $130 \mathrm{~K}$ on an Agilent Xcalibur automatic diffractometer equipped with an AtlasS2 two-coordinate detector (graphite monochromator, $\lambda\left(\mathrm{Mo}_{\alpha}\right)=0.71073 \AA$, $\omega$-scan). Integration, absorption corrections, and unit cell parameters were determined using the CrysAlisPro software package. The crystal structures were solved using the SHELXT program and refined by full-matrix least squares in the anisotropic (except for hydrogen atoms) approximation using the SHELXL program [37]. The positions of hydrogen atoms were calculated geometrically and refined according to the "riding" model. Crystallographic data and details of diffraction experiments are given in Table 1. Complete tables of interatomic distances and bond angles, atomic coordinates, and atomic displacement parameters have been deposited with the Cambridge Crystallographic Data Center (CCDC nos. 2068994, 2068995).

$\mathrm{X}$-ray powder diffraction studies of polycrystals was carried out on a Shimadzu XRD-7000 diffractometer $\left(\mathrm{Cu} K_{\alpha}\right.$ radiation, $\mathrm{Ni}$-filter, OneSight linear detector, $2 \theta$ angle range $5^{\circ}-50^{\circ}, 2 \theta$ step $0.0143^{\circ}$, accumulation at a point $2 \mathrm{~s}$ ). Samples for the study were prepared as follows: polycrystals were ground in an agate mortar in the presence of heptane, the resulting suspension was applied to the polished side of a standard quartz cell. After drying of heptane, the sample was a thin even layer $(\sim 100 \mu \mathrm{m}$ thick).

Thermogravimetric analysis was carried out on a TG 209 F1 Iris thermal balance (Germany). The measurements were carried out in a flow of helium in the 


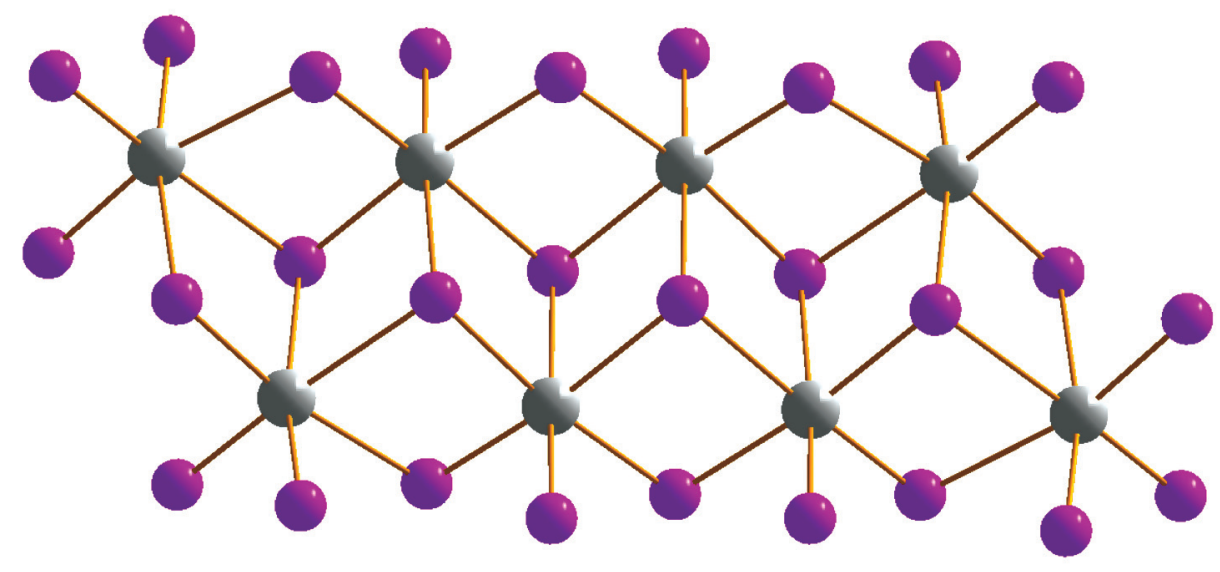

Fig. 1. Structure of anion $\left[\alpha-\mathrm{Bi}_{8} \mathrm{I}_{28}\right]^{4-}$ in compound $\mathbf{1}$.

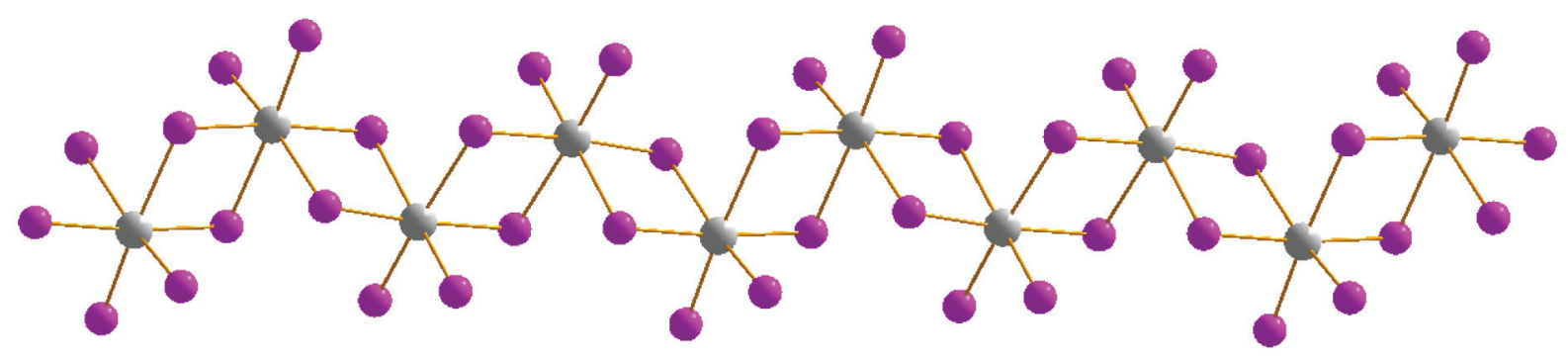

Fig. 2. Structure of anion $\left[\mathrm{BiI}_{4}\right]^{-}$in compound 2.

temperature range $30-450^{\circ} \mathrm{C}$ at a heating rate of $10 \mathrm{~K} / \mathrm{min}$ in open aluminum crucibles.

Optical properties. The diffuse reflectance spectra of the powders were recorded using a spectrophotometric system consisting of a Kolibri-2 spectrometer (VMC Optoelektronika, Russia), an Avantes FCR7UVIR400-2-ME-HT reflection/backscattering probe, and an AvaLight-DHS deuterium-tungsten lamp (Avantes, Netherlands). The spectra were recorded in the wavelength range of 300-1000 $\mathrm{nm}$ at room temperature relative to the standard of $100 \%$ reflection which was powder barium sulfate $\mathrm{BaSO}_{4}$.

\section{RESULTS AND DISCUSSION}

As noted earlier [1], the factors affecting the composition and structure of metal halides include the nature of the cation, the salt of which is used in the synthesis, as well as the ratio of reagents and the nature of the solvent [38]. The role of the latter factor has been studied scarcely, although individual examples demonstrating its importance have been described [39].

When the reaction was carried out in an acetonitrile solution at a reagent ratio of $2: 1\left(\mathrm{BiI}_{3}\right.$ : CatI), iodobismuthate 1 with a discrete octanuclear anion was obtained (Fig. 1). Complex compounds with an anion of a similar structure are already known [40, 41], although they are few in number. In this anion, eight bismuth atoms are located on two parallel straight lines and are linked by $\mu_{2-}$ and $\mu_{3}$-bridging iodide ligands. The lengths of the $\mathrm{Bi}-\mathrm{I}_{\text {term }}, \mathrm{Bi}-\mu_{2}-\mathrm{I}$, and $\mathrm{Bi}-$ $\mu_{3}$-I bonds in 1 are in the ranges $2.848-2.904,2.931-$ 3.457 , and 3.059-3.455 $\AA$, respectively.

When carrying out the reaction in $\mathrm{CH}_{3} \mathrm{CN}$ with a different ratio of reagents $(1: 1)$, we failed to obtain single crystals suitable for X-ray diffraction; however, they were obtained using a mixture of acetone and acetonitrile. According to the results of X-ray diffraction, the anion in $\mathbf{2}$ has a polymer structure (Fig. 2). This structural type (type E according to our proposed classification [1]) occurs quite often [42, 43]. In the structure of this anion, the $\left\{\mathrm{BiI}_{6}\right\}$ octahedra are linked by two pairs of $\mu_{2}$-bridging ligands (Fig. 2) and form an endless polymer chain. The lengths of the $\mathrm{Bi}-\mathrm{I}_{\text {term }}$ and $\mathrm{Bi}-\mu_{2}-\mathrm{I}$ bonds in 2 fall in the ranges $2.942-2.919$ and 3.038-3.282 $\AA$, respectively. Packings in crystals 1 and 2 are shown in Figs. 3 and 4, respectively.

According to X-ray powder diffraction data, samples $\mathbf{1}$ and $\mathbf{2}$ are single-phase, which made it possible to study their thermal stability and optical properties. According to TGA data (Fig. 5), both compounds 

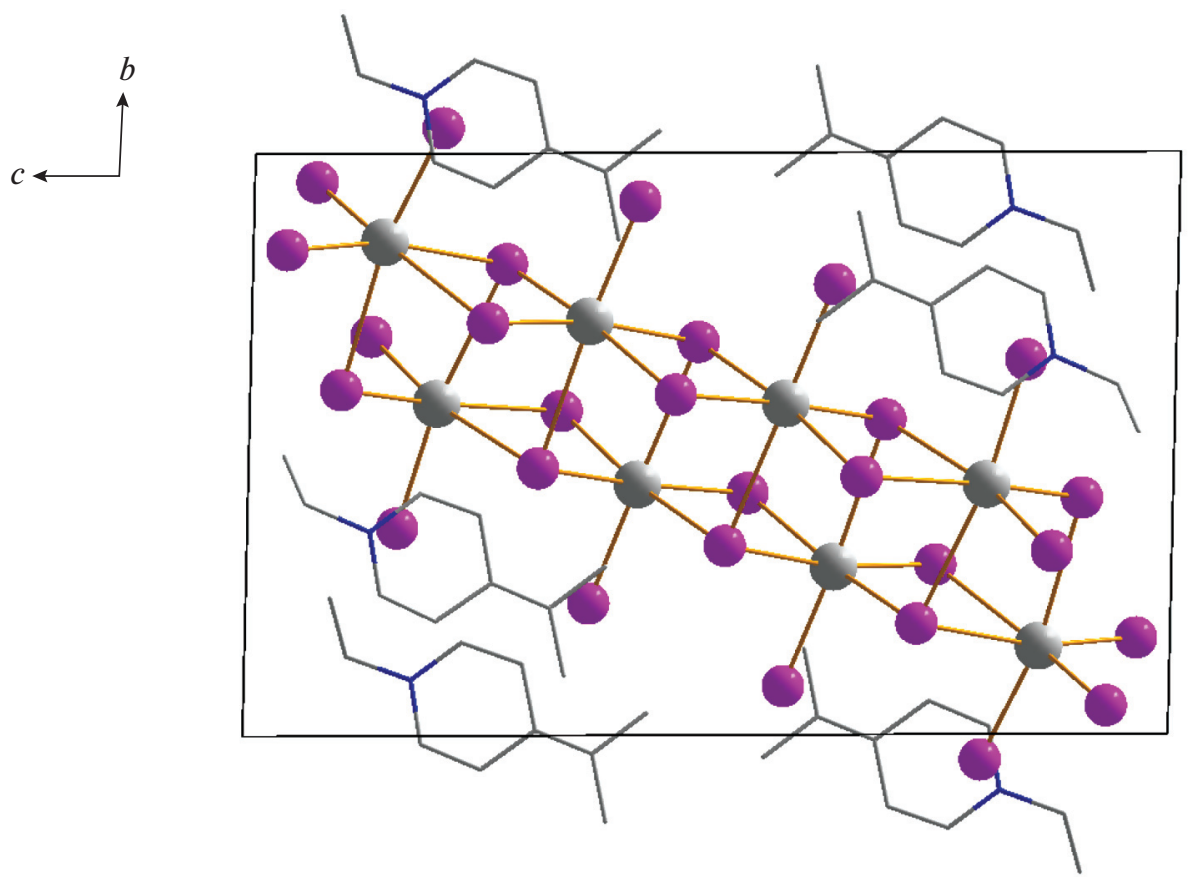

Fig. 3. Crystal packing in the structure of $\mathbf{1}$.
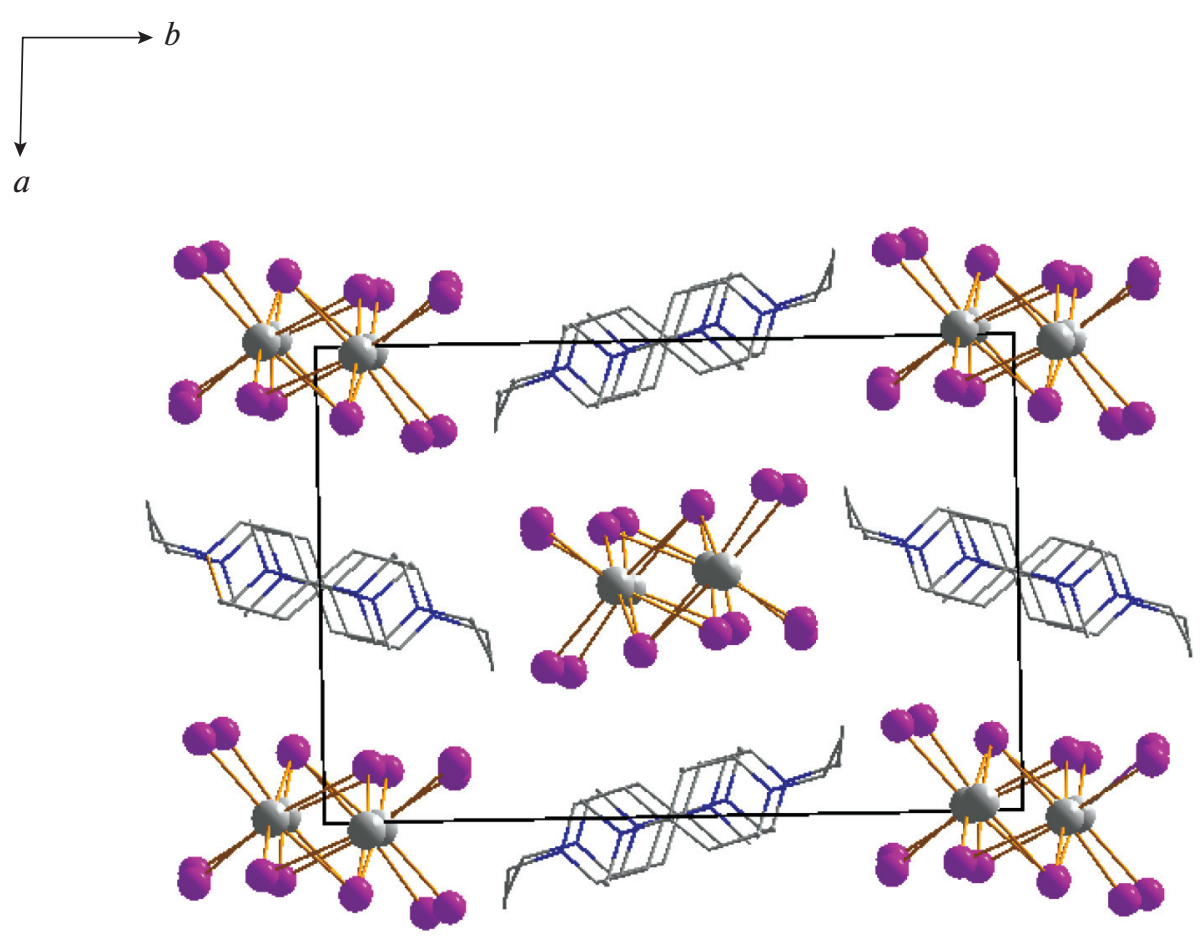

Fig. 4. Crystal packing in the structure of 2.

decompose at temperatures $>300^{\circ} \mathrm{C}$, but $\mathbf{1}$ demonstrates higher stability. Diffuse reflectance spectra are shown in Fig. 6. They have a clear absorption edge and are similar to each other. To determine the band gap, these spectra were recalculated into absorption spectra using the Kubelka-Munk formula. The band gap was calculated from the absorption spectra in the Tauz coordinates and amounted to 1.92 and $1.93 \mathrm{eV}$ for $\mathbf{1}$ and 2 , respectively, which is comparable with the data $[44,45]$. 


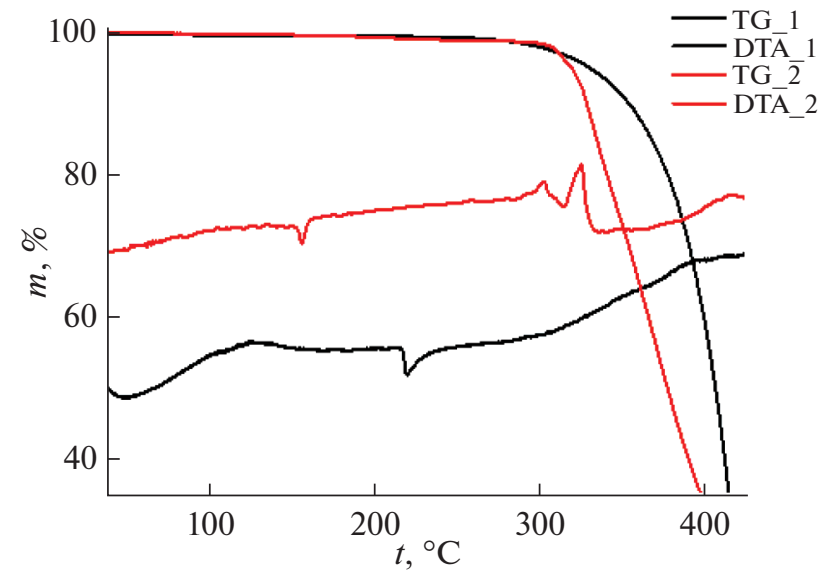

Fig. 5. Thermal analysis data for compounds 1 (black) and 2 (red).

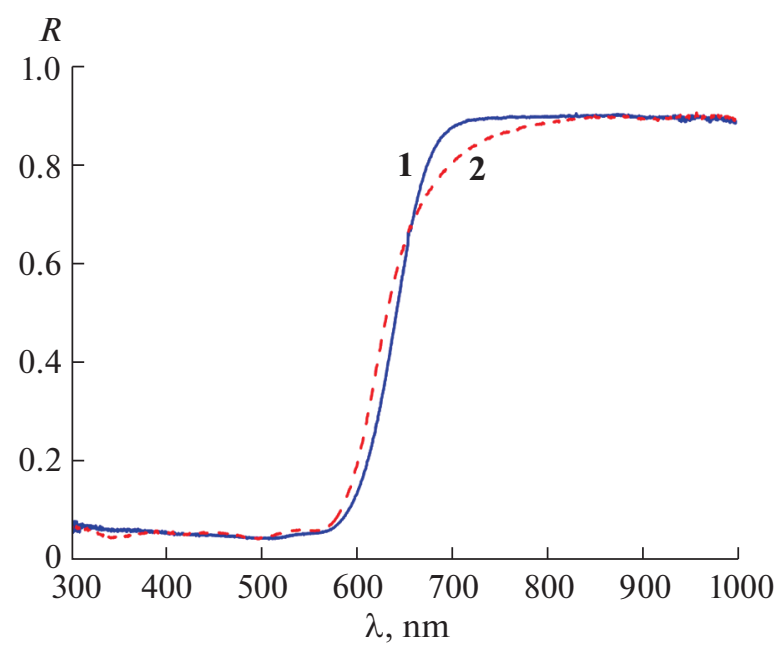

Fig. 6. Diffuse reflectance spectra of compounds 1 (blue) and $\mathbf{2}$ (red).

\section{FUNDING}

This work was supported by the Russian Science Foundation (project no. 18-73-10040).

\section{CONFLICT OF INTEREST}

The authors declare that they have no conflicts of interest.

\section{OPEN ACCESS}

This article is licensed under a Creative Commons Attribution 4.0 International License, which permits use, sharing, adaptation, distribution and reproduction in any medium or format, as long as you give appropriate credit to the original author(s) and the source, provide a link to the Creative Commons license, and indicate if changes were made. The images or other third party material in this article are included in the article's Creative Commons license, unless indicated otherwise in a credit line to the material. If material is not included in the article's Creative Commons license and your intended use is not permitted by statutory regulation or exceeds the permitted use, you will need to obtain permission directly from the copyright holder. To view a copy of this license, visit http://creativecommons.org/licenses/by/4.0/.

\section{REFERENCES}

1. S. A. Adonin, M. N. Sokolov, and V. P. Fedin, Coord. Chem. Rev. 312, 1 (2016). https://doi.org/10.1016/J.CCR.2015.10.010

2. H. Eickmeier, B. Jaschinski, A. Hepp, et al., Z. Naturforsch, Sect. B 54, 305 (1999).

3. M. A. Tershansy, A. M. Goforth, M. D. Smith, et al., Acta Crystallogr., Sect. E 62, M3269 (2006). https://doi.org/10.1107/S1600536806043960

4. V. V. Sharutin, I. V. Egorova, M. V. Levchuk, et al., Russ. J. Coord. Chem. 28, 613 (2002). https://doi.org/10.1023/A:1020082731096

5. V. V. Sharutin, I. V. Yegorova, N. N. Klepikov, et al., Russ. J. Inorg. Chem. 54, 52 (2009). https://doi.org/10.1134/S0036023609010124

6. A. M. Goforth, M. A. Tershansy, M. D. Smith, et al., Acta Crystallogr., Sect. C 62, M381 (2006). https://doi.org/10.1107/S0108270106025972

7. A. M. Goforth, L. R. Peterson, M. D. Smith, et al., J. Solid State Chem. 178, 3529 (2005). https://doi.org/10.1016/j.jssc.2005.09.010

8. K. Y. Monakhov, C. Gourlaouen, R. Pattacini, et al., Inorg. Chem. 51, 1562 (2012). https://doi.org/10.1021/ic201859c

9. N. A. Yelovik, T. A. Shestimerova, M. A. Bykov, et al., Russ. Chem. Bull. 66, 1196 (2017). https://doi.org/10.1007/s11172-017-1872-y

10. T. A. Shestimerova, A. V. Mironov, M. A. Bykov, et al., Cryst. Growth Des. 20, 87 (2020). https://doi.org/10.1021/acs.cgd.9b00636

11. P. A. Buikin, A. Y. Rudenko, A. B. Ilyukhin, et al., Russ. J. Coord. Chem. 46, 111 (2020). https://doi.org/10.1134/S1070328420020049

12. A. N. Usoltsev, M. Elshobaki, S. A. Adonin, et al., J. Mater. Chem. A 7, 5957 (2019). https://doi.org/10.1039/C8TA09204D

13. S. Pandey, A. P. Andrews, and A. Venugopal, Dalton Trans. 1, 8705 (2016). https://doi.org/10.1039/c6dt01032f

14. G. Xu, G.-C. Guo, M.-S. Wang, et al., Angew. Chem., Int. Ed. 46, 3249 (2007). https://doi.org/10.1002/anie.200700122

15. J. Heine, Dalton Trans. 10069 (2015). https://doi.org/10.1039/c5dt00813a

16. T. A. Shestimerova, N. A. Yelavik, A. V. Mironov, et al., Inorg. Chem. 57, 4077 (2018). https://doi.org/10.1021/acs.inorgchem.8b00265

17. T. A. Shestimerova, N. A. Golubev, N. A. Yelavik, et al., Cryst. Growth Des. 18, 2572 (2018). https://doi.org/10.1021/acs.cgd.8b00179

18. T. A. Shestimerova, A. V. Mironov, M. A. Bykov, et al., Molecules 25, 2765 (2020). 
19. N. A. Yelovik, A. V. Mironov, M. A. Bykov, et al., Inorg. Chem. 55, 4132 (2016).

https://doi.org/10.1021/acs.inorgchem.5b02729

20. D. B. Mitzi, Inorg. Chem. 39, 6107 (2000). https://doi.org/10.1021/ic000794i

21. O. V. Rudnitskaya, E. K. Kultyshkina, E. V. Dobrokhotova, et al., J. Struct. Chem. 60, 1086 (2019). https://doi.org/10.1134/S0022476619070096

22. V. V. Sharutin, O. K. Sharutina, and E. V. Lobanova, Russ. J. Inorg. Chem. 65, 870 (2020). https://doi.org/10.1134/S0036023620060200

23. V. V. Sharutin, O. K. Sharutina, and V. S. Senchurin, Russ. J. Inorg. Chem. 65, 1712 (2020). https://doi.org/10.1134/S0036023620110170

24. V. R. Shayapov, A. N. Usoltsev, S. A. Adonin, et al., New J. Chem. 43, 3927 (2019). https://doi.org/10.1039/C9NJ00320G

25. A. Gagor, M. Weclawik, B. Bondzior, et al., CrystEngComm 17, 3286 (2015). https://doi.org/10.1039/C5CE00046G

26. D.-H. Wang, L.-M. Zhao, X.-Y. Lin, et al., Inorg. Chem. Front. 5, 1162 (2018). https://doi.org/10.1039/C7QI00755H

27. B. V. Bukvetskii, T. V. Sedakova, and A. G. Mirochnik, Russ. J. Coord. Chem. 38, 106 (2012). https://doi.org/10.1134/S1070328412020017

28. B. V. Bukvetskii, T. V. Sedakova, and A. G. Mirochnik, Russ. J. Inorg. Chem. 56, 213 (2011). https://doi.org/10.1134/S0036023611020045

29. B. V. Bukvetskii, T. V. Sedakova, and A. G. Mirochnik, Russ. J. Coord. Chem. 36, 651 (2010). https://doi.org/10.1134/S1070328410090034

30. P. Wang, Z. R. Chen, and H. H. Li, J. Clust. Sci. 31, 943 (2020). https://doi.org/10.1007/s10876-019-01699-1

31. R.-G. Lin, G. Xu, G. Lu, et al., Inorg. Chem. 53, 5538 (2014). https://doi.org/10.1021/ic5002144

32. J.-J. Shen, X.-X. Li, T.-L. Yu, et al., Inorg. Chem. 55, 8271 (2016). https://doi.org/10.1021/acs.inorgchem.6b01599
33. A. A. Petrov, I. P. Sokolova, N. A. Belich, et al., J. Phys. Chem. C 121, 20739 (2017). https://doi.org/10.1021/acs.jpcc.7b08468

34. S. A. Fateev, A. A. Petrov, V. N. Khrustalev, et al., Chem. Mater. 30, 5237 (2018). https://doi.org/10.1021/acs.chemmater.8b01906

35. N. A. Belich, A. S. Tychinina, V. V. Kuznetsov, et al., Mendeleev Commun. 28, 487 (2018). https://doi.org/10.1016/j.mencom.2018.09.011

36. E. I. Marchenko, S. A. Fateev, A. A. Petrov, et al., J. Phys. Chem. C 123, 26036 (2019). https://doi.org/10.1021/acs.jpcc.9b08995

37. G. M. Sheldrick, Acta Crystallogr., Sect. C 71, 3 (2015). https://doi.org/10.1107/S2053229614024218

38. A. N. Usoltsev, N. A. Korobeynikov, A. S. Novikov, et al., Inorg. Chem. 59, 17320 (2020). https://doi.org/10.1021/acs.inorgchem.0c02599

39. I. A. Ahmed, R. Blachnik, and H. Reuter, Z. Anorg. Allg. Chem. 627, 2057 (2001). https://doi.org/10.1002/1521-3749(200109)627:9<2057:: AID-ZAAC2057>3.0.CO;2-7

40. V. V. Sharutin, I. V. Egorova, N. N. Klepikov, et al., Russ. J. Inorg. Chem. 54, 239 (2009). https://doi.org/10.1134/S0036023609020120

41. H. Krautscheid, Z. Anorg. Allg. Chem. 621, 2049 (1995). https://doi.org/10.1002/zaac.19956211212

42. W. Bi, N. Leblanc, N. Mercier, et al., Chem. Mater. 21, 4099 (2009). https://doi.org/10.1021/cm9016003

43. N. Leblanc, N. Mercier, M. Allain, et al., J. Solid State Chem. 195, 140 (2012).

https://doi.org/10.1016/j.jssc.2012.03.020

44. Z.-P. Zhang, Q.-Y. Feng, Q.-L. Wang, et al., J. Clust. Sci. 29, 367 (2018). https://doi.org/10.1007/s10876-018-1339-9

45. Z. P. Zhang, Q. Y. Feng, Y. L. Wei, et al., J. Clust. Sci. 29, 725 (2018). https://doi.org/10.1007/s10876-018-1397-z

Translated by V. Avdeeva 